\title{
Studies on the systematics and taxonomy of the genus Hylaeus F. (9) Supplement to the taxonomy and distribution of Afrotropical Hylaeus F. species (Hymenoptera: Anthophila, Colletidae)
}

With 25 figures

Holger H. Dathe ${ }^{1}$

${ }^{1}$ Senckenberg Deutsches Entomologisches Institut, Eberswalder Straße 90, 15374 Müncheberg, Germany. - holger.dathe@ senckenberg.de

Published on 2015-06-30

\section{Summary}

A new subgenus, Hylaeus (Pumilaeus) subgen. nov., and four new species of different subgenera of Hylaeus are described: Hylaeus (Alfkenylaeus) euphorbiae spec. nov., Hylaeus (Cornylaeus) adamauanis spec. nov., Hylaeus (Deranchylaeus) haladanius spec. nov. and Hylaeus (Pumilaeus) pumilus spec. nov. The synonymy of Hylaeus namaquensis Cockerell, 1942 with H. (Alfkenylaeus) stictifrons (CoCKereld, 1936) syn. nov. is stated; Hylaeus arnoldi (Friese, 1913) is confirmed as a species of the Hylaeus subgenus Alfkenylaeus (stat. nov.). The placement of the new taxa requires a series of modifications to the classification by SNELLING (1985). The species are inserted in the existing identification keys, and a new key to the Afrotropical subgenera of Hylaeus is presented. Additional data on the geographical distribution and floral visits of species are given.

\section{Key words}

Africa, bee taxonomy, new subgenus, new species, synonyme, identification key, distribution

\section{Zusammenfassung}

Es werden ein neues Subgenus, Hylaeus (Pumilaeus) subgen. nov., und vier neue Arten aus verschiedenen HylaeusSubgenera beschrieben: Hylaeus (Alfkenylaeus) euphorbiae spec. nov., Hylaeus (Cornylaeus) adamauanis spec. nov., Hylaeus (Deranchylaeus) haladanius spec. nov. und Hylaeus (Pumilaeus) pumilus spec. nov. Als neues Synonym wurde Hylaeus namaquensis Cockerell, $1942=$ H. (Alfkenylaeus) stictifrons (CoCKerell, 1936) festgestellt; Hylaeus arnoldi (FrIESE, 1913) wird bestätigt als zugehörig zum Hylaeus-Subgenus Alfkenylaeus (stat. nov.). Die Einordnung der neuen Taxa bedingt eine Reihe von Modifikationen des Systems von SnELling (1985). Die Arten werden an die bestehenden Bestimmungstabellen angeschlossen, aber auch für die afrotropischen Hylaeus-Subgenera wird eine neue Tabelle vorgeschlagen. Außerdem werden weitere Daten zur geografischen Verbreitung und zum Blütenbesuch der Arten gegeben.

\section{Introduction}

Recent works on the species-rich subgenera Hylaeus (Deranchylaeus) (DATHe 2014) and Hylaeus (Nothylaeus) (SNELLING et al., in preparation) revise most historic

data on the Hylaeus species of the Afrotropical Region. These studies, the first of which was by SNELLING (1985), provide for the first time a comprehensive and critical 
overview of the entire genus, based on about 100 years of collecting activity. Taking into account the large size of the Region and its biological richness, our present knowledge can however only be understood as a suitable basis for further, more targetted research.

SNELLING (1985) presented a general picture of the groups within Hylaeus and revised the smaller subgenera. Here, I place new results and insights which have been obtained since then in the context of the framework that he erected.

In his initial overview, Snelling distinguished six subgenera. One more is added here, so that currently seven can be reckoned with. The parameters defined by Snelling were adopted by all subsequent authors (MICHENER 2000: 193 et seq., 2007: 202 et seq., EARDLEY et al. 2010: 23 et seq., Dathe 2014). EARdley \& Urban (2010: 6) estimated from a review of the literature that the genus Hylaeus in the Afrotropical Region contains a total of 89 valid species. According to our revisions, the seven subgenera now contain only about 70 species, including the taxa here described as new, because numerous names proved to be synonyms.

Hylaeus (Alfkenylaeus) SNELLING, 1985 - 6 species Hylaeus (Cornylaeus) Snelling, 1985 - 3 species

Hylaeus (Deranchylaeus) BRIDwELL, 1919 - 32 species Hylaeus (Metylaeus) BRIDwELL, 1919 - 6 species

Hylaeus (Nothylaeus) BRIDwell, 1919 -21 species (according to provisional manuscript)

Hylaeus (Prosopisteron) Cockerell, 1906 - 1 species (in Africa)

Hylaeus (Pumilaeus) DATHE, subgen. nov. - 1 species

\section{Methods and terminology}

This study is based on hitherto unexamined material in the South African collections in Cape Town, Grahamstown and Pretoria (SANC), as well as the Biologiezentrum Linz, the Royal Belgian Institute of Natural Sciences, Brussels, and the Kuhlmann collection (London). A useful quantity of data is thus available, although these are surely at present far from being complete. Accordingly, it seems pragmatic to restrict the scope of the present work to indicating the gaps in our knowledge and the unsolved problems, while simultaneously providing the best possible identification keys with which research can be continued.

For the participating museums, the following abbreviations are used in the text:

AMG Albany Museum, Grahamstown, South Africa

HBRC Holeta Bee Research Centre, Addis Ababa, Ethiopia

MNHN Muséum National d'Histoire Naturelle, Paris, France
MNHU Museum für Naturkunde, Leibniz-Institut für Evolutions- und Biodiversitätsforschung, Berlin, Germany

NHML The Natural History Museum, London, UK

OLBL Oberösterreichisches Landesmuseum, Biologiezentrum, Linz, Austria

RBINS Royal Belgian Institute of Natural Sciences, Brussels, Belgium

SAMC Iziko Museums of Cape Town [including Rhodesia Museum], South Africa

SANC South African National Collection of Insects, Agricultural Research Council, Pretoria, South Africa

SDEI Senckenberg Deutsches Entomologisches Institut, Müncheberg, Germany

USNM Smithsonian National Museum of Natural History, Washington, USA

The morphological terminology follows Dathe (2014):

CL Clypeal length. The median length of the clypeus from the basal to the apical margin.

CW Clypeal width. The distance between the clypeal margins at the level of the tentorial pits.

HL Head length. The maximum midline distance between the occipital margin and the apical margin of the clypeus in frontal view.

HW Head width. The maximum breadth of the head in frontal view, across the eyes.

LFW Lower facial width. The minimum distance between the eyes at their lower ends.

UFW Upper facial width. The maximum distance between the eyes at their point of greatest width. The relationship UFW: LFW is used to express the degree of convergence of the inner eye margins.

SL Scapus length. Maximum length of the scapus without the basal condylus.

SW Scapus width. Width of the scapus at its broadest point.

T1, T2 Metasomal tergum, T1 being the first tergum, T2 the second, and so on.

S1, S2 Metasomal sternum, S1 being the first, S2 the second, and so on. Sterna 7 and 8 of the males are mainly of importance as parts of the "terminalia”.

TL Total length. This is difficult to assess because of (for example) the telescopic construction of the metasoma, but for practical reasons is indispensable.

WL Wing length. The length of the anterior wing, from the tegular margin to the forewing tip.

The structure of the integument surface, especially the gradation of punctation, is standardized in the following manner: 


\begin{tabular}{|c|c|}
\hline $\begin{array}{l}\text { Punctation strength } \\
\text { (without discrete } \\
\text { measure in } \mathrm{mm} \text { ) }\end{array}$ & $\begin{array}{l}\text { Punctation relative density } \\
\text { (interspace distance } d \text { relative to } \\
\text { puncture diameter) }\end{array}$ \\
\hline $\begin{array}{l}\text { minute } \\
\text { fine } \\
\text { moderate } \\
\text { strong } \\
\text { coarse } \\
\text { very coarse }\end{array}$ & $\begin{array}{ll}\text { contiguous } & d=0 \\
\text { subcontiguous } & d=0.25 \\
\text { dense } & d=0.3-0.7(0.5) \\
\text { close } & d=0.7-1.5 \\
\text { sparse } & d=2-3 \\
\text { scattered } & d=\text { ca. } 3-6\end{array}$ \\
\hline
\end{tabular}

These terms are used as a pair in the descriptions to describe strength and density of the punctation, the two qualities being separated by a comma, e.g. "the clypeus of $H$. euphorbiae spec. nov. has a moderate, sparse punctation".

\section{Taxonomy and distribution}

\section{Identification key to Afrotropic subgenera of Hylaeus F.}

Modified from Snelling (1985: 5-6), Michener (2007: 202-203) and EArdley et al. (2010: 23-24).

1 Supraclypeal area elevated between antennal sockets and laterally margined; propodeum with defined basal area, usually coarsely rugose or roughened or sharply punctate, at least in part

- Supraclypeal area gently sloping from midline to antennal sockets, not laterally margined; propodeum smooth, densely tessellate, without defined basal area; entire body densely tessellate, with conspicuous punctures

\section{H. (Prosopisteron) COCKERELL}

2 Mandibles slim falcate, apically acuminate without distinct teeth; mandibles elongate, slender, without grooves and ridges on outer surface

H. (Nothylaeus) BRIDWELL

- Mandibles transverse or oblique truncate, with two or three teeth; mandibles short and broad, with the usual grooves and ridges on outer surface

3 Integument of head and mesosoma very coarsely punctate; punctation often pit-like and widely spaced; scutellum and metanotum each frequently with a pair of lateral spines; metanotum of females if without spines at least with a laterally marginate around median area. Occipital carina present, sharp; lateral edges of pronotum acute; omaulus sharply carinate. Male terminalia: S7 with extended, lamellate distal lobus, S8 with short blunt apical lobus, genitalic capsule with obtuse apically blackened gonoforcipes H. (Metylaeus) BRIDWELL

- Integument variously punctate; if head and mesosoma coarsely punctate, then occipital border only edged and/or propodeum rounded; scutellum and metanotum without lateral spines or margins. Occipital carina often absent; omaulus not sharply carinate but sometimes with an obscure ridge. Male terminalia different

4 Male, antenna 13-segmented, S5 smooth, without apical brush ....................................................................... 5

- Female, antenna 12-segmented, S5 with blunt-triangular apical brush .............................................................. 8

\section{Males}

5 S7 with two apical lobes, apical lobes of S7 slender, directed laterally or basolaterally, at most with small tenuous setae; genital capsule with prolonged gonoforcipes, exceeding apex of penis valves, distally often conspicuously narrowed, apex without or short bristles

H. (Alfkenylaeus) SNELLING

- S7 with four apical lobes, the proximal pair usually with thick setae or teeth; genital capsule with gonoforcipes terminating bluntly at about level of apex of penis valves, apical not attenuate, with long bristles

6 Apical lobes of S7 expanded to convex bubble-like lamellae, the small proximal lobes lamellar as well, without bristles; S8 with prolonged bifurcate apical lobus, its parts with fine marginal hairs. Pronotum not anteriorly expanded ...

H. (Pumilaeus) subgen. nov.

- Apical lobes of S7 not formed as bubble-like lamellae, apical and proximal lobes are usually distinctly sclerotized appendages with bristles or teeth; S8 with blunt or spatula-like apical lobus, not bifurcate. Pronotum usually expanded forward

7 S7 of characteristic shape: distal lobes sclerotized, darkened, aside attenuate, without distinct bristles; proximal lobes with triangular outline; genital capsule with compact gonoforcipes, penis valves slim. Metasoma covered with abundant erect fine hairs, particularly on distal segments. Clypeus with a bright vertical stripe in the middle, if white parts extended, then laterally distinct black borders remain H. (Cornylaeus) SNELLING 
- S7 of different shape, its appearance very diverse, in a prevalent basic form, the proximal lobes bearing distinct long setae, while the distal lobes are formed as flags. Metasoma mostly with few or no erect hairs. Mask diverse, but rarely consisting of three lines

H. (Deranchylaeus) BRIDWELL

Females

8 Supraclypeal area usually bounded laterally by two fine outwardly curved carinae; anterior margin of pronotum often sharp-edged

- Supraclypeal area laterally edged, but without elevated carinae; anterior margin of pronotum rounded or edged, but not sharp

9 Pronotum distinctly expanded, especially lateral; propodeum often with angular edges; legs usually only black and white H. (Deranchylaeus) BRIDWELL

- Pronotum not expanded, in dorsal view, the anterior margin follows the frontal mesonotum contour; propodeum rounded; legs wholly or in part red

H. (Alfkenylaeus) SNELLING

10 Larger species of 7-9 mm TL; mask often with three bright stripes; dorsal border of the mandibles flatly expanded; front terga with abundant erect hairs on discs H. (Cornylaeus) SNELling

- Smaller species of 5-6 mm TL; mask with long extended, filling side spots and a small dot on the clypeus; mandibles normal, dorsal border straight; front terga without abundant erect hairs on discs .... H. (Pumilaeus) subgen. nov.

\section{Subgenus Hylaeus (Alfkenylaeus) SNeLLING, 1985}

\section{Species included}

H. acariphorus SNELLING, 1985

H. arnoldi (FRIESE, 1913) stat. nov.

H. infulatus SNELLING, 1985

H. psaenythioides SNELLING, 1985

H. stictifrons (COCKERELL, 1936)

$=H$. namaquensis COCKerell, 1942 syn. nov.

H. euphorbiae spec. nov.

\section{Hylaeus (Alfkenylaeus) acariphorus SNELLING, 1985} Figures 1, 2; cover

SNELLING (1985: $14 \mathrm{ff}$.) described his new species based on a male (holotype) from Zimbabwe and a female from
South Africa. He also mentioned two females with ferruginous T1 from Kenya, which he considered to be probably conspecific. This assumption can now be confirmed by new material from Kenya, Mozambique and Zimbabwe. The Kenyan specimens are slightly smaller and have the base of the metasoma reddish brown (Figs 1,2), but the principal characters agree. A special feature in both sexes is the rimmed triangular impression at the metasomal articulation, in which mites are usually to be found (see also cover picture).

Distribution: South Africa, Zimbabwe (EARDLEY \& URBAN 2010: 26); new to Ethiopia, Kenya and Mozambique.

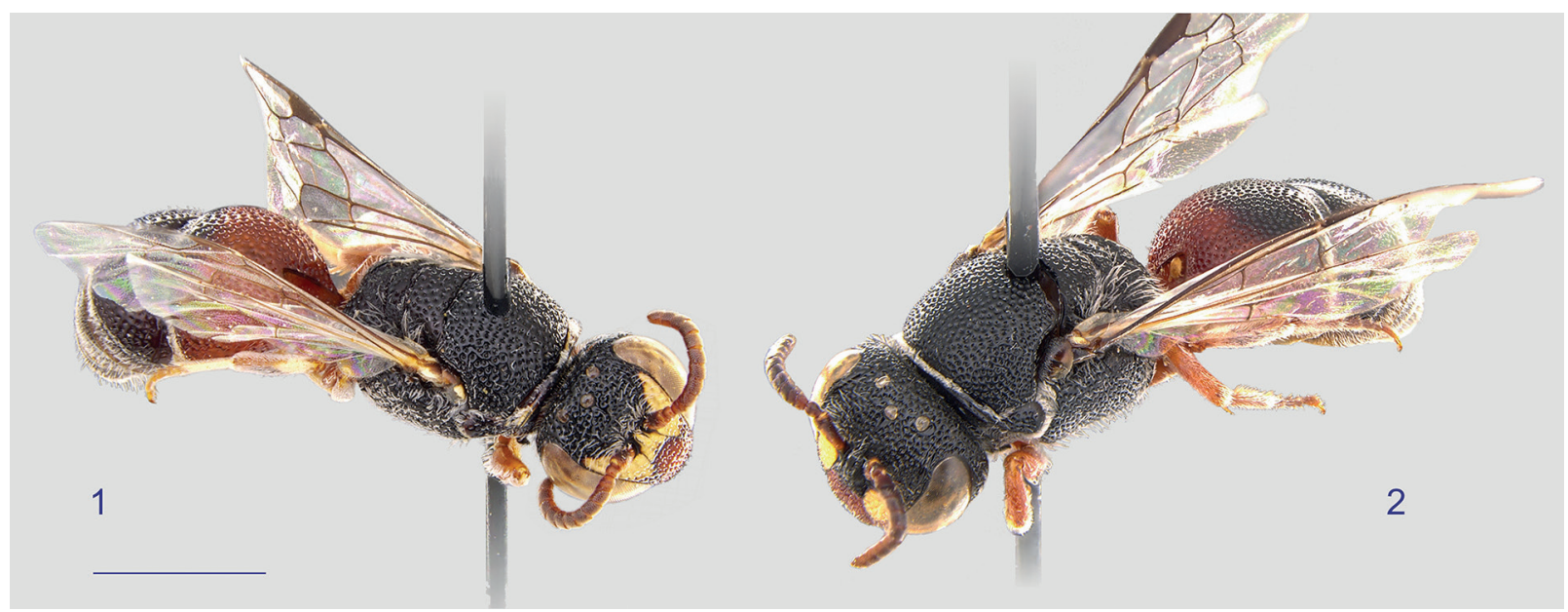

Figs 1-2: Hylaeus (Alfkenylaeus) acariphorus SNELLING, 1985. Male (left) and female of red variant; specimens from Kenya, Tsavo National Park East. - Scale $2 \mathrm{~mm}$. 


\section{New records:}

Ethiopia: Southern road to Elbere, $05^{\circ} 20^{\prime} 48^{\prime \prime N} 36^{\circ} 57^{\prime} 49^{\prime \prime E}$, 559 m, 24.09.2012, 1 o 1 ㅇ, on Indigofera, A. Pauly lg. - In coll. RBINS, HBRC.

Kenya: SE, Voi Safari Lodge env., Tsavo National Park East, 08.-18.11.1996, 1 o $^{\star} ; 22.11 .-02.12 .1996,140^{\text {* }}$ 6 ; ; 23.03.-04.04.1997, $1 \sigma^{*}$, all M. Halada lg.; 10.12.1999, 1 ㅇ, M. Snižek lg. - Kenya CEE, E of Garsen, W of Witu, 19.12.2009, 1 ; ; E of Mwingi, W of Nguni, 01.12.2010, $60^{\star} 6$ ㅇ, M. Snižek lg - In coll. OLBL, SDEI.

Mozambique: CW, $30 \mathrm{~km}$ NW Catandica, $17^{\circ} 47^{\prime} \mathrm{S}$ $33^{\circ} 07^{\prime} \mathrm{E}, 930 \mathrm{~m}, 29.11 .2005,1 \mathrm{o}^{\top}, 15 \mathrm{~km} \mathrm{~S}$ Guro 17³3'S $33^{\circ} 16^{\prime} \mathrm{E}, 800 \mathrm{~m}, 30.11 .2005,10^{\top}$; $40 \mathrm{~km}$ SW Chimoio, $19^{\circ} 23^{\prime} \mathrm{S} 33^{\circ} 11^{\prime} \mathrm{E}, 650 \mathrm{~m}, 16.12 .2005,1$ i ; all Kadlecová lg. - In coll. OLBL.

\section{Hylaeus (Alfkenylaeus) arnoldi (FrIESE, 1913)}

Hylaeus arnoldi should also be included (or remain) in the subgenus Alfkenylaeus, although the male terminalia partly constitute special structures (S8). Snelling himself (1985: $18 \mathrm{ff}$.) ran this species in his determination key to Hylaeus (Alfkenylaeus). He treated it as a separate subgenus, but could not reach a final decision on the basis of his data.

In H. arnoldi, the gonoforcipes of the male genital capsule are significantly extended, but not shaped like narrow styli. Sterna 7 and 8 are independent formations sui generis, but at least in the case of S7 are imaginable as a transitional form: the apical part can be interpreted as a ridge, the basal part as a lamella, as they appear in the other species of the group. The lobes of S8 are special structures without direct equivalents. A number of not insignificant characters seem to contradict these controversial findings. The species appear very close to each other: the sculpture of head, meso- and metasoma is smooth and shiny, the punctation strenght is strong to coarse, the pilosity is striking, white and erect, the propodeum is regularly domed just as in the other H. (Alfkenylaeus) species. SNELling (1985: 13) outlines a number of features of the occipital edge, the pronotum, the mesepisterna, the gradulus, etc. In the males, the supraclypeal area is clearly set off from the frons surface, and the face drawings of females immediately remind one of $H$. (Alfkenylaeus) species, except that they differ clearly in the punctation of basal terga 1 and 2. In both sexes, the base of $\mathrm{T} 1$ shows a pronounced rimmed triangular impression as in $H$. acariphorus. However, definitive information on the taxonomic distance can probably only be provided by a DNA analysis. Until then I do not see a reason to keep H. arnoldi separate. Michener (2000: 194, 2007: 203) discussed the problems and reached a similar conclusion.

Distribution: Namibia, Zimbabwe (EARdLey \& UrbaN 2010: 27); new to Botswana, Kenya and Mozambique.
New records:

Botswana: North of Maun, Island Sateri 01.-31.01.1997, $1 \sigma^{\star}$, M. Snižek lg. - In coll. SDEI.

Kenya: Mpala Research Centre, 10.06.1999, 3 ㅇ, on Acacia gerrardii, G.N. Stone lg. - In coll. SANC, SDEI. Mozambique: Manicata pr., $70 \mathrm{~km}$ SE Chimoio, 2324.12.2003, 1 o $^{\star} 1$ ㅇ , J. Halada lg. - In coll. OLBL.

\section{Hylaeus (Alfkenylaeus) stictifrons (CoCKERELL, 1936)}

Prosopis stictifrons Cockerell, 1936 p: 633 o', SW Africa [Namibia]: Windhoek, 12.xii.1933 J. Ogilvie. Typus o NHM London, B.M. TYPE HYM. 17.a.31.

Hylaeus (Deranchylaeus) stictifrons (CockerelL): SNELling 1985: 8.

Hylaeus stictifrons (COCKERELL): EARDLEY \& URBAN 2010: 36. Hylaeus namaquensis CocKerell, 1942: 2, 4, 12-13 11 ㅇ, $100^{7}$, South-West Africa [Namibia]: Aus (Windhoek, Kaoko Otavi), January 1930, R.E. Turner lg. Syntypes NHM London. - EARDLEY \& URBAN 2010: 33. - Syn. n.

Hylaeus (Alfkenylaeus) namaquensis CoCKerell: SNELling 1985: 13-14, 16-18. Michener 2000: 194.

Hylaeus stictifrons (Cockerell) is listed in SNELling (1985: 8) as a species belonging to Hylaeus (Deranchylaeus). The study of the type revealed, however, that it actually belongs to the subgenus $H$. (Alfkenylaeus). In this type specimen, the gonostyli are probably broken or worn, so they appear a little shorter. Nevertheless, I have no doubt that it is identical with $H$. (Alfkenylaeus) namaquensis, described later by CoCKERELL - new synonym.

Distribution: Namibia (EARDLEY \& URBAN 2010: 36).

\section{Hylaeus (Alfkenylaeus) euphorbiae spec. nov. \\ Figures $3,4,22$}

Diagnosis: This new species, of which only males are so far available, is relatively small and has less pronounced sculpture than the hitherto known representatives of the subgenus Hylaeus (Alfkenylaeus). It differs mainly in that the gonoforcipes are only extended, and do not form gonostyli.

Description: Male. - TL 4.8-5.5 (5.12) mm, WL 3.7-4.5 (4.12) $\mathrm{mm}$.

Head. Proportions HL:HW 0.87-0.94 (0.90), UFW:LFW 1.62-1.66 (1.64), outline rounded trapezoid. Scapus slender, SL:SW 1.62-1.66 (1.64), black above, becoming brownish below, one specimen with yellow spot at tip; flagellum long, yellow, dark above. Mask complete, yellow, lateral markings on orbits far reaching. Foveae faciales short and very narrow. Clypeus CL:CW 1.33-1.41 (1.37), shiny, with moderate, sparse punctation; anterior margin with a row of bristles. Supraclypeal area dorsally 
with lateral edges sharply bent up, truncate to frons, without transition. Frons and vertex with moderately dense, extensive pilosity. Genae and malar areas narrow, occiput midst with edged posterior margin. Labrum and mandibles brown.
Mesosoma. Shape regular, pilosity distinct, white, moderately long and dense, erect; longer on ventral side. Mesosoma black, except pronotum with two yellow stripes and tegulae with yellow spots. Pronotum narrow, not extended; anterior margin only sharp in middle,

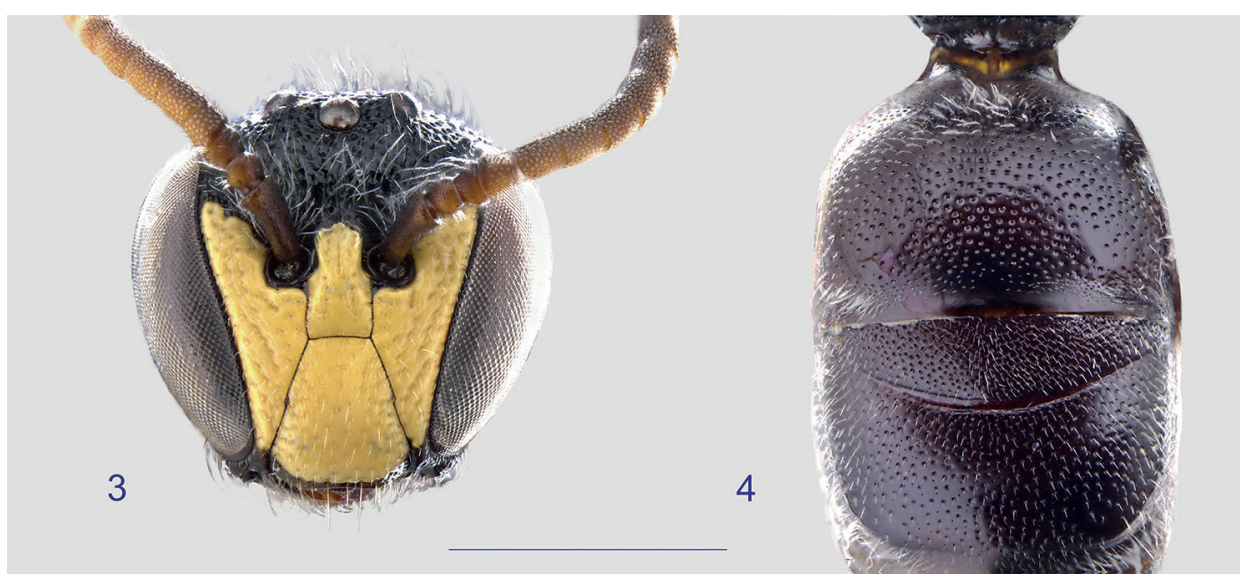

Figs 3-4: Hylaeus (Alfkenylaeus) euphorbiae spec. nov., typus male: 3 head in frontal view, 4 surface structure of basal terga in dorsal view. - Scale $1 \mathrm{~mm}$.

Key to species of the subgenus Hylaeus (Alfkenylaeus) SNELLING

Modified from SNELLing (1985: 13-14).

1 Female, antenna 12-segmented 2

- Male, antenna 13-segmented

2 Apical protarsal segment broadest at apex, evenly narrowed toward base; bristles of protarsus slightly or not at all flattened, their apices acuminate; T1 and T2 with close, coarse punctation

- Apical protarsal segment narrowest basad, broadened to basal one-third, evenly narrowed apicad; protarsal bristles strongly flattened, apices bluntly rounded; T2 either without evident punctation or punctation fine and scattered arnoldi (FRIESE)

3 Clypeus entirely black; legs brownish, metatibiae with basal one-third more or less yellowish; T2-T5 with conspicuous preapical pubescent fasciae

- Clypeus largely ferruginous; legs entirely ferruginous; T3-T5 with short, inconspicuous hairs, a little denser on side of $\mathrm{T} 1$ and $\mathrm{T} 2$ acariphorus SNELLING

4 Punctation along middle of clypeus fine to moderate, separated by one-half, or more, puncture diameters; pronotum maculate; hairs on basal face of T1 long, fully erect, and continuous across summit stictifrons (COCKERELL)

- Punctation along middle of clypeus coarse, contiguous to subcontiguous; pronotum unmarked; hairs on basal face of T1 subappressed and limited to margin of sulcus, none across summit infulatus SNELLING

5 Clypeus entirely pale or pale with apical area ferruginous; lateral face mark filling most of space between complex eyes and clypeus; thorax often dull, punctural interspaces densely tessellate

- Clypeus black on upper two-thirds, apical one-third ferruginous; transverse stripe between antennal sockets and clypeal base yellowish; thoracic interspaces shiny, polished on dorsum psaenythioides SNELLING

6 Sternum 3 flat, without mediobasal glabrous swelling; base of metatibia and entire metatarsus whitish 7

- Sternum 3 with low, semicircular glabrous swelling at base; legs wholly ferruginous acariphorus SNELLING

7 Lateral face marking ending at level of upper margin of antennal sockets; scape with white stripe beneath arnoldi (ALFKEN)

- Lateral face marking ending midway between antennal sockets and top of eye; scape unmarked beneath 8

8 Gonoforcipes of genital capsule with gonostyli stictifrons (COCKERELL)

- Gonoforcipes of genital capsule without gonostyli euphorbiae spec. nov. 
otherwise rounded, dorsolateral angle blunt. Mesonotum and scutellum shiny, very finely shagreen, with strong, sparse punctation; metanotum matt; mesopleura smooth and shining, with strong, close punctation. Legs black, bright basally on tibiae, frontally on foretibiae and whole of tarsi. Wings hyaline, venation brown. Propodeum rounded, evenly domed, its surface wrinkled, dull; basal area delineated by fine carina, surface reticulate-wrinkled; terminal area not delimited, medial furrow short, flatly extended above.

Metasoma slender spindle- to cone-shaped; black, base with erect white pilosity. Sculpture of T1 smooth and shiny, with strong, close punctation, apically finer, end margin smooth without punctation; T2 basally deeply impressed, with conspicuous transverse furrow reaching nearly to lateral margin; apical margin ends with rounded transition. T1 with white lateral fringes, and ciliar bands on depressions. Terminalia of stictifrons-type (Fig. 22); genital capsule with gonoforcipes rounded at tip, not developed into narrow styli; S7 and 8 as in $H$. stictifrons.

Distribution: South Africa.

Type material: $30^{\text {t. }}$.

Holotypus: $0^{\top}$ South Africa: Western Cape: Knersvlakte, Kalkgat $31^{\circ} 07^{\prime} 30^{\prime \prime} \mathrm{S} 18^{\circ} 55^{\prime} 30^{\prime \prime} \mathrm{E}, 18 .-27.08 .2000$, U. Schmiedel \& M. Kuhlmann lg. - In coll. SDEI.

Paratypes: South Africa: Western Cape: Travellers Rest, Sevilla $32^{\circ} 04^{\prime} 374^{\prime \prime S} 19^{\circ} 04^{\prime} 837^{\prime \prime E}, 328$ m, 25.08.2007, 1 o", Stanway lg. Northern Cape: Bushmanland, Pofadder 01.-31.10.1939, 1 o $^{\star}$ Mus.staff lg. - Both in coll. SAMC.

Flower visit: On flowers of Euphorbia mauritanica (Euphorbiaceae); record by Stanway from Western Cape, South Africa.

Derivatio nominis: One of the specimens was caught when visiting flowers of Euphorbia mauritanica.

Discussion: Determining the specimens according to the table in SNELling (1985: 5), one arrives at the subgenus Deranchylaeus. The species is distinguished from Hylaeus (Alfkenylaeus) by the rounded ends of the gonoforcipes instead of the requested styli, while the other features correspond more closely to the subgenus Alfkenylaeus than to Deranchylaeus. Also, sterna 7 and 8 show no similarity to Deranchylaeus, and the new species is clearly more similar to other species of the subgenus Alfkenylaeus, closest to H. stictifrons (Cockerell, 1936).

Therefore it seems reasonable not to restrict the definition of Hylaeus (Alfkenylaeus) to species with narrow, stylus-like gonoforcipes, especially since the prolonged gonoforcipes of $H$. euphorbiae spec. nov. can also be interpreted as a transition to a more extreme shape of styli.

\section{Subgenus Hylaeus (Cornylaeus) SNELLING, 1985}

Species included

H. aterrimus (FRIESE, 1911)

= Prosopis quinquedentata FrIEse, 1911

= Hylaeus pondonis COCKERELL, 1942

H. proteae Cockerell, 1942

$H$. adamauanis spec. nov.

\section{Hylaeus (Cornylaeus) aterrimus (FRIESE, 1911)}

Distribution: South Africa, Zimbabwe; on flowers of Protea sp. (EARDley \& URBAN 2010:27); new to Mozambique.

New records:

Mozambique: Inhambane: Massinga $25 \mathrm{~km} \mathrm{~N}$, 05.-29. 12.2003, 1 ه 1 ㅇ , J. Halada lg.; NW, 65 km S Vlóngné, $15^{\circ} 13^{\prime} \mathrm{S} 34^{\circ} 19^{\prime} \mathrm{E}, 1250 \mathrm{~m}, 08.12 .2005,24$ o $^{*} 41$ 우 Kadlecová lg. - In coll. OLBL, SDEI.

South Africa: Mpumalanga: Lydenbrug $30 \mathrm{~km} \mathrm{NE}, \mathrm{nr}$ Ohrig, 09.-12.01.2004, 2 o 2 ㅇ, J. Halada lg. - In coll. OLBL. Natal: Durban, 01.-31.05.1916, 1 , BellMarley lg. [Transvaal], Wolkberg, 13.04.1974, 1 o 1 우, R.H. Watmoughlg. Honingklip, 2601'35"S 27²4'08"E, 18.11.2005, 1 ๙ $^{\star} \mathrm{M}$. Forsyth lg. - In coll. SANC.

Zimbabwe [Rhodesia]: Bulawayo, 24.11.1916, 1 우 Rhodesia Museum lg. 07.11.1954, $2 \sigma^{\star}$, Nat. Mus. S. Rhodesia lg. Salisbury, 1 , , A. Watsham lg. - In coll. SANC. Chimanimani Nature Park, 14.12.1998, 1 o $^{\star}$, M. Halada lg. - In coll. OLBL. Chishawasha, 01.-30.06.1980, 2 ㅇ, A. Watsham lg. - In coll. NHML.

\section{Hylaeus (Cornylaeus) proteae CoCKereLL, 1942}

Distribution: South Africa, Zimbabwe; on flowers of Protea sp. (EARDley \& Urban 2010: 34).

New records:

South Africa: [no locality, label “1239”], 13.02.1960, 1 ๙ 1 ㅇ, V. Strubens lg. - In coll. SANC. Mpumalanga: Lydenbrug $30 \mathrm{~km}$ NE, nr Ohrig, 09.-12.01.2004, 1 \% , J. Halada lg. - In coll. OLBL.

Hylaeus (Cornylaeus) adamauanis spec. nov. Figures 5-9, 23

Diagnosis: According to the male terminalia, this small species belongs clearly to $H$. (Cornylaeus). It differs in both sexes from the two previously known larger species of this subgenus in its bright legs, the ferruginous metasoma base and white axillae. The male has a narrow scape. 


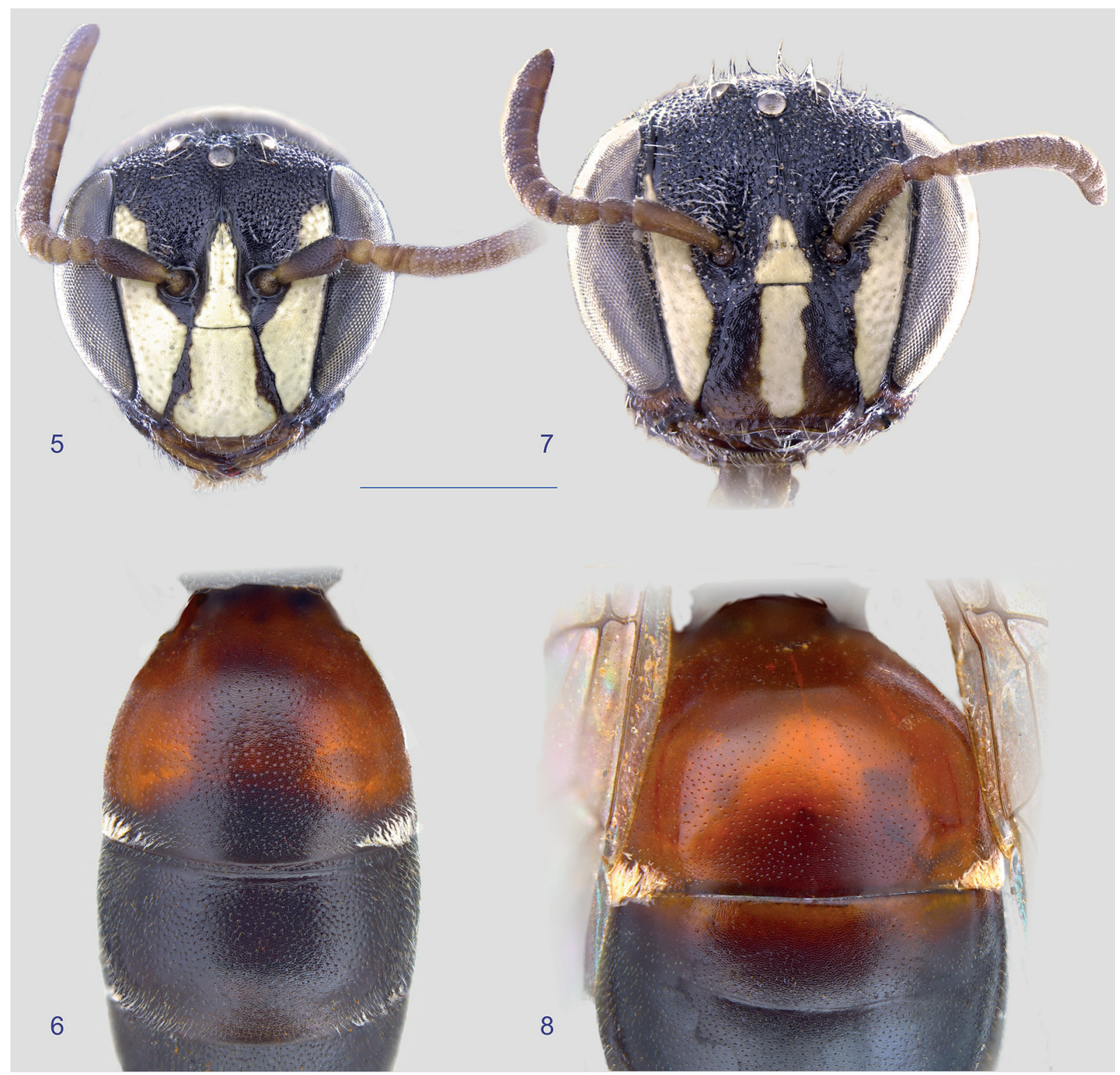

Figs 5-8: Hylaeus (Cornylaeus) adamauanis spec. nov.: head in frontal view and surface structure of basal terga in dorsal view. 5, 6 Typus male. - 7, 8 Paratypus female. - Scale $1 \mathrm{~mm}$.

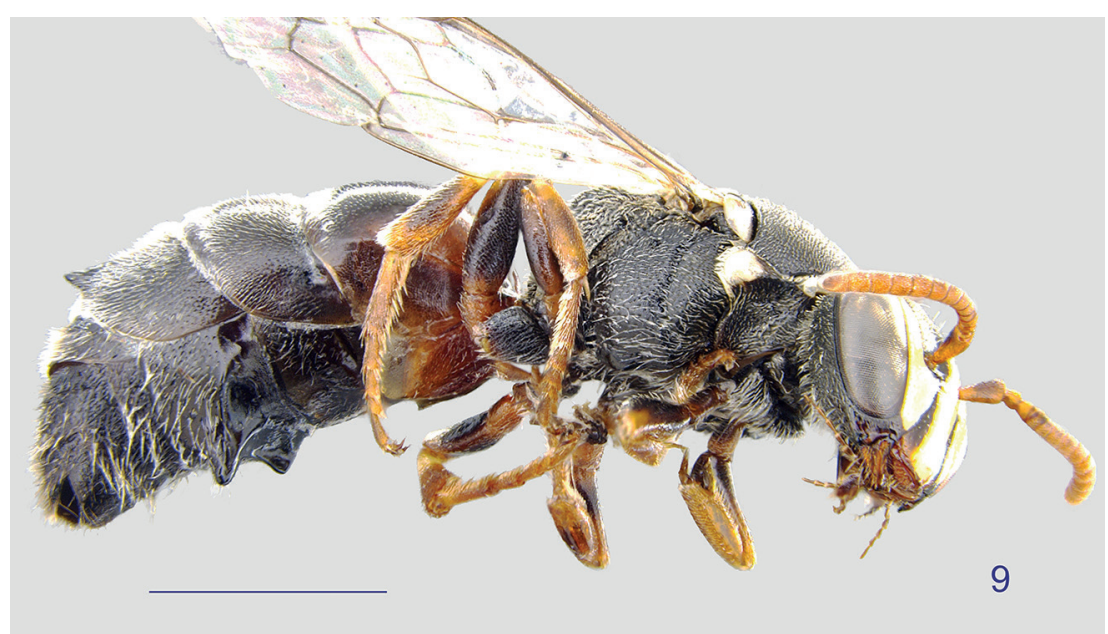

Fig. 9: Hylaeus (Cornylaeus) adamauanis spec. nov.: Paratypus male, ventrolateral habitus. - Scale $2 \mathrm{~mm}$. 
Description: Male. - TL 5.2-5.6 (5.42) mm, WL 3.7-4.0 (3.86) $\mathrm{mm}$.

Head. Proportions HL:HW 0.88-0.91 (0.89), UFW:LFW 1.31-1.40 (1.36), outline transverse trapezoid. Scapus brown, conoid, as wide as flagellum, SL:SW 1.88-2.49 (2.18); flagellum short, yellow, segments seamed brown, therefore appearing annulated. Mask bright yellow, clypeus laterally with extended black margins, so mask appears three-streaked. Foveae faciales short, visible as a smooth bar. Clypeus CL:CW 1.14-1.20 (1.17), silkily shining, with strong, scattered punctation. Supraclypeal area narrow, top tapering to a point. Pilosity on frons and vertex short, inconspicuous, punctation moderate, subcontiguous. Genae regular, middle occipital margin sharp, malar areas relatively wide, about equal to width of scapus. Labrum and mandibles light brown.

Mesosoma. Outline compact, pilosity dorsally short, sparse, white, ventrally and around metanotum long and erect. Coloration black, bright are line on pronotum, spots on calli and tegulae and anterior scutellar corners (axillae). Pronotum little expanded, with bright stripe; front edge rounded, dorsolateral angle blunt. Mesonotum shagreen, silkily shiny, with moderate, dense punctation; scutellum shiny, punctation more dispersed. Mesopleurae similarly sculptured to metanotum, but punctation more shallow. Sternum mediodistally with strong impression. Legs brown, somewhat brighter are tibiae basally, foretibiae frontally and tarsi. Wings brownish, venation brown. Propodeum rounded, shagreen and silkily shining; basal area only indistinctly delimited, without carina, surface basally with a row of stitches, distally with irregular ridges; terminal area without sharp edge, shallowly punctate, medial furrow deeply impressed.

Metasoma slender spindle-shaped; coloration black, base of T1 yellow brown. Sculpture of T1 finely striate, shiny, with moderate, sparse punctation, following terga similar; T1 with narrow white lateral fringes, T2 with loose rows of cilia on depression; S3 with flat, obtuse-triangular callosity. Terminalia of cornylaeus-type (Fig. 23). Genital capsule with compact gonoforcipes, penis valves slim; S8 with somewhat extended apical lobus, distal lobes of S7 sclerotized.

Female. - TL $5.92 \mathrm{~mm}$, WL $4.47 \mathrm{~mm}$.

Head. Proportions HL:HW 0.87, UFW:LFW 1.26, outline transverse elliptic. Scapus light brown; flagellum short, light brown. Mask ivory white, appearing three-striped: paraocular lines at reaching foveae, clypeus and supraclypeal area in middle with broad stripe. Fovea facialis long, distinct. Clypeus CL:CW 1.03, below with a triangular brown area, sculpture fine-grained, silkily shining, with strong, sparse to scattered punctation. Supraclypeal area narrowed above, shallowly merging to frons. Frons and vertex with subcontiguous coarse flat punctation. Genae and occiput regular; malar areas, labrum and mandibles brown as in male.

Mesosoma. Outline compact, slightly depressed; pilosity sparse, as in male. Coloration black, bright are pronotal stripe, calli, dots on tegulae and axillae at anterior edges of scutellum. Pronotum little expanded, dorsolateral angle blunt. Mesonotum and mesopleurae shagreen, silkily shining, with moderate, dense punctation, shallower on mesopleurae; scutellum shiny, punctation more scattered. Legs entirely light brown. Wings light brownish, venation brown. Propodeum rounded, matt, surface densely tomentose. Basal and terminal areas as described in male.

Metasoma slender spindle-shaped. T1 brown, other parts of metasoma with black coloration. Sculpture of T1 very finely shagreen, shiny, with minute, sparse punctation; the following terga similar. T1 and T2 with narrow white lateral fringes, terminal fringe yellowish.

\section{Distribution: Cameroon.}

Type material: $120^{\star}, 1$.

Holotypus: o Cameroon: Adamaoua, Beka nr Ngaoundere $07^{\circ} 17^{\prime} \mathrm{N} 13^{\circ} 19^{\prime} \mathrm{E}, 24.07 .1987$; on Protea, A. Pauly lg. - In coll. RBINS.

Paratypes: Cameroon: Adamaoua, Beka nr Ngaoundere, $07^{\circ} 17^{\prime} \mathrm{N} 13^{\circ} 19^{\prime} \mathrm{E}, 24.07 .1987,1 \sigma^{\top} 1$ \% ; on Protea (same data as holotypus); Adamaoua: de Banyo à Tibati, $06^{\circ} 37^{\prime} \mathrm{N} 12^{\circ} 07^{\prime} \mathrm{E}, 26.07 .1987,10^{\star}$; Adamaoua: Tékel, $06^{\circ} 47^{\prime} \mathrm{N} 13^{\circ} 10^{\prime} \mathrm{E}, 24.07 .1987,20^{\circ}$; N Mayo-Darlé, $06^{\circ} 28^{\prime} \mathrm{N}$ $11^{\circ} 33^{\prime} \mathrm{E}, 23.07 .1987,20^{\circ}$; all A. Pauly lg. Meiganga $06^{\circ} 33^{\prime} \mathrm{N} 14^{\circ} 15^{\prime} \mathrm{E}, 1103 \mathrm{~m}, 08 .-24.05 .2014,5$ ơ , Y.B. Soukontoua lg. - In coll. RBINS, SANC, SDEI.

Flower visit: On flowers of Protea sp. (Proteaceae) and Harungana madagascariensis (Hypericaceae); all records by A. Pauly.

Derivatio nominis: The epitheton is an adjective and refers to the province Adamaoua in Cameroon.

Remarks: Two of the twelve males available for study possess the same conspicuous five tuberculate processes on the metasoma which are already known in Hylaeus (Cornylaeus) aterrimus. Here it led to the description of a junior synonym Prosopis quinquedentata FrIESE, 1911, see also Fig. 18 in Snelling (1985: 11). This corresponds to the situation in $H$. adamauanis spec. nov. (Fig. 9): T3 has two lateral cone-shaped pegs, and the base of S3 is transversely depressed to form a shiny, welldefined plate whose distal margin bears processes at three points. These structures are frequently only developed in outlines. According to Snelling, the different degrees of development of the processes fall well within the range of variation of $H$. aterrimus, as he understood the species. The available material of the new species is not very extensive, but shows no continuous transition between a morph with missing processes and that in which these are well developed. Observations on the biological function of these remarkable structures would therefore be desirable. 
Key to species of the subgenus Hylaeus (Cornylaeus) SNELLING

Modified from SNELLING (1985: 10).

1 Female, antennae 12-segmented

- Male, antennae 13-segmented

2 Clypeus with median stripe; supraclypeal area maculate

- Clypeus and supraclypeal area black

proteae COCKERELL

3 Scapi, legs and base of T1 black, calli and axillae without white spot aterrimus (FRIESE)

- Scapi, legs and base of T1 ferruginous, calli and axillae white adamauanis spec. nov.

4 Scapi more or less spherically extended, black, shiny; axillae and T1 black 5

- Scapi slender, black and more or less lightened brownish, few glossy; axillae white, base of T1 ferruginous adamauanis spec. nov.

5 Clypeus with longitudinal stripe; basitibiae with basal pale mark; T3 often with lateral tubercles; S3 tuberculate or not; scapi longer than broad aterrimus (FRIESE)

- Clypeus black or with a minute preapical median spot; basitibiae wholly dark; T3 always without lateral tubercles; S3 with a large median swelling; scapi rotund, as broad as long proteae (COCKERELL)

\section{Subgenus Hylaeus (Deranchylaeus) BrIDWELL, 1919}

Species included: 31 species are revised by DATHE (2014), together with this new description a total of 32 species is known.

\section{Hylaeus (Deranchylaeus) haladanius sp. n.} Figures 10-17, 24

Diagnosis: This species is small and dainty, and characterized by its strong sculpture. It exhibits large and shallow punctures on pro- and mesosoma; in contrast, the metasoma is only finely sculptured. The males have remarkably long antennae.

Description: Male. - TL 4.1-4.8 (4.45) mm, WL 3.0-3.4 (3.21) $\mathrm{mm}$.

Head. Proportions HL:HW 0.97-1.00 (0.98), UFW:LFW 1.67-1.81 (1.74), outline approximately circular, with clypeus expanded downward. Scapus black, short conoid, narrower than flagellum, SL:SW 1.7-1.8 (1.78). Flagellum conspicuously long, yellow from segment 1, increasingly becoming darker toward apex and dorsally. Mask white to light yellow, supraclypeal area black, lateral markings tapering to orbits, terminating above bases of scapi. Foveae faciales short, forming raised bars. Clypeus CL:CW 1.34-1.51 (1.42), matt, moderately punctate, punctures with indistinct borders. Supraclypeal area black, basally with only a few large shallow pits; apically narrowed, delimited by high margins, here with close punctation. Frons and vertex nearly without pilosity; area of scapus bases with denser and finer punctation, otherwise with coarse, close punctation. Genae narrowed below, occiput rounded, malar area distinctly formed. Labrum and mandibles black.

Mesosoma compact, slightly elongated, pilosity very sparse and short. Black, bright are only tegulae spots. Pronotum black, distinctly expanded; anterior margin sharp over entire width, with stepped frontbar; dorsolateral angle pointed and bent. Mesonotum and scutellum silkily shining, shagreen with large shallow punctures; mesopleurae similar. Metanotum with sharp wrinkled meshes as on basal area of propodeum. Legs black, white tibial bases, foretibiae in front and whole tarsi. Wings brownish, venation light brown. Propodeum margined, its surface usually shiny; basal and lateral areas delimited by carinae, with raised edges around wrinkled meshes; terminal area surrounded by sharp margins.

Metasoma narrow and slender, black. Sculpture of T1 with microscopic fine grooves, punctation minute, scattered, following terga without punctation. Terga without side fringes on depressions. Terminalia see Fig. 24; genital capsule with prolonged gonoforcipes, these blackened in apical region; S8 compact with short lobes only as in curvicarinatus-group(2); S7 also similar to H. curvicarinatus, but with reduced lobes and without bristles.

Female. - TL 4.7-5.5 (5.10) mm, WL 3.2-3.8 (3.49) mm. Head. Proportions HL:HW 0.98-1.01 (0.99), UFW:LFW 1.49-1.60 (1.55), outline rounded trapezoid, scarcely hairy. Scapus black; flagellum of normal length, black, basoventrally partly yellow. Face totally black, in a few specimens (Central African Republic) with tiny white spots below on paraocular areas. Fovea facialis short, expanded and more distinct on vertex; foveal groove continues downwards as narrow wrinkled line, sepa-

Figs 10-17 (opposite page): Hylaeus (Deranchylaeus) haladanius spec. nov.: head in frontal view; mesosoma lateral and dorsal; surface structure of basal terga in dorsal view. - 10-13 Typus male. - 14-17 Paratypus female. - Scale $1 \mathrm{~mm}$. 


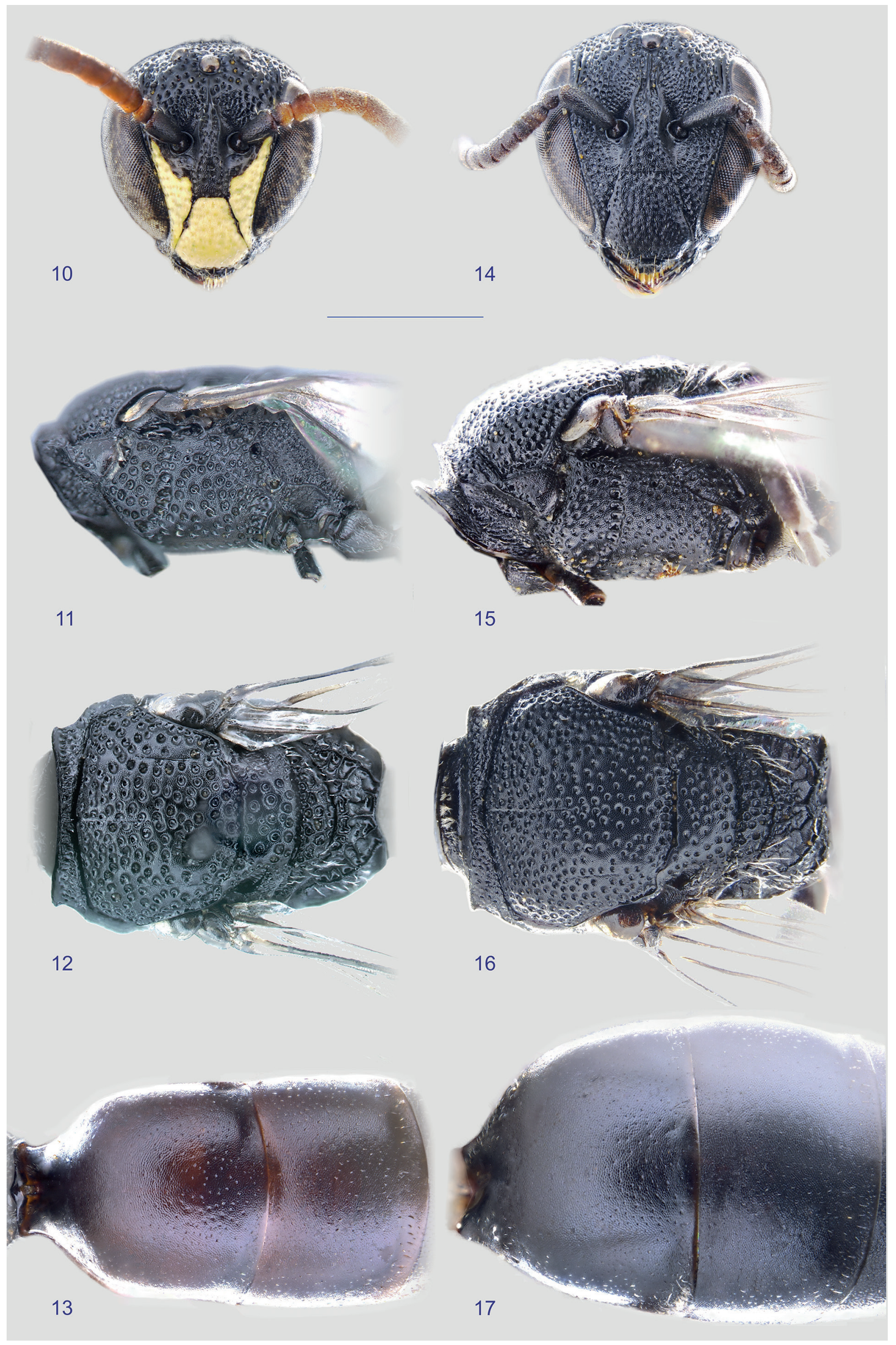


rated from adjacent face by a distict edge; this structure continues nearly around complex eye. Clypeus CL:CW 1.11-1.20 (1.16), shagreen, silkily shining, punctation only superficial and unclear. Upper supraclypeal area narrow, almost parallel-sided, above merging widely into the frons. Frons and vertex with moderate, dense punctation, scapus area densely but unclearly punctate, with white tomentum. Genae with large shallow punctation, occiput marginate, malar areas significant. Labrum with horseshoe-shaped callus, mandibles rounded bilobed.

Mesosoma extended, slightly depressed, without pilosity. Coloration entirely black, only tegulae with light spots. Pronotum black, expanded, front margin raised, dorsolateral angle bent. Mesonotum and scutellum shagreen, silkily shining, with strong, dense punctation; mesopleura similarly sculptured to mesonotum, punctation larger and shallower; omaulus edged. Metanotum matt, strongly punctate. Legs entirely black, without light marks. Wing membrane brown, venation brown. Propodeum margined; basal area with marginally limited meshes similar to males, but not quite as pronounced; terminal area enclosed by sharp margins.

Metasoma slender spindle-shaped, black. T1 very finely shagreen, silkily shining, with only extremely minute, scattered punctation or without punctures, the following terga without punctation. Depressions of T1 with sparse ciliar fringes. Ventral end of fringe light yellowish.

Distribution: Burundi, Cameroon, Central African Republic, Nigeria, South Africa, Zambia.

Type material: $18 \sigma^{\star}, 41$ 우 .

Holotypus: $\sigma^{\top}$ Burundi: Ruvubu National Park, Ruvubu River, $02^{\circ} 59.20^{\prime} \mathrm{S} 30^{\circ} 28.12^{\prime} \mathrm{E}, 1401 \mathrm{~m}, 05.11 .2010$, C.D. Eardley lg. - In coll. SANC.

Paratypes: Burundi: Ruvubu National Park, Ruvubu River, $02^{\circ} 59^{\prime} 20^{\prime \prime S} 30^{\circ} 28^{\prime} 12^{\prime \prime E}, 1401 \mathrm{~m}, 05.11 .2010,2$ o $^{\top} 4$ 우 (same data as holotype), C.D. Eardley lg. - In coll. SANC, SDEI.

Cameroon: Adamaoua: Beka nr Ngaoundere, $07^{\circ} 17^{\prime} \mathrm{N}$ $13^{\circ} 19^{\prime} \mathrm{E}, 24.07 .1987,30^{\star} 3$ + , on Sapindaceae; Adamaoua: de Banyo à Tibati, $06^{\circ} 37^{\prime} \mathrm{N} 12^{\circ} 07^{\prime} \mathrm{E}, 26.07 .1987,30^{\top} 12$ 웅 Adamaoua: Louga W Ngaoundere, $07^{\circ} 05^{\prime} \mathrm{N} 13^{\circ} 12^{\prime} \mathrm{E}$, 24.07.1987, 1 o $^{\top} 1$ i ; Adamaoua: Massif du Mbam, Jakiri, $06^{\circ} 01^{\prime} \mathrm{N} 10^{\circ} 33^{\prime} \mathrm{E}, 22.07 .1987,1$ \% ; Adamaoua: MayoDarlé, $06^{\circ} 28^{\prime} \mathrm{N} 11^{\circ} 33^{\prime} \mathrm{E}, 24.07 .1987,10^{\top 1} 1$ ㅇ ; Adamaoua:

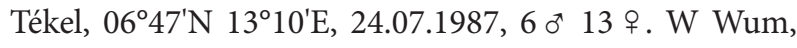
$06^{\circ} 24^{\prime} \mathrm{N} 10^{\circ} 03^{\prime} \mathrm{E}, 20 .-07.1987,2$ 우 ; all A. Pauly lg. - In coll. RBINS.

Central African Republic: $85 \mathrm{~km}$ NW Bangui, $04^{\circ} 46^{\prime} \mathrm{N}$ $18^{\circ} 04^{\prime} \mathrm{E}, 380 \mathrm{~m}, 04.04 .2010,2$ \% ; $90 \mathrm{~km} \mathrm{~N}$ Carnot, $05^{\circ} 36^{\prime} \mathrm{N}$ $15^{\circ} 54^{\prime} \mathrm{E}, 820 \mathrm{~m}, 03.06 .2009,1$ \% ; all J. Halada lg. - In coll. OLBL, SDEI.

Nigeria: Gashaka Gumfi NP, 30 km SE Serti env., $07^{\circ} 21^{\prime} \mathrm{N}$ $11^{\circ} 32^{\prime} \mathrm{E}$, ca. $450 \mathrm{~m}, 24.04 .-08.05 .2011,1$ ㅇ , J. Halada lg. In coll. OLBL.
South Africa: Eastern Cape: $18 \mathrm{~km}$ S Vosburg, 3055'48"S $24^{\circ} 56^{\prime} 05^{\prime \prime E}, 31.01 .2011,10^{*}$, C.D. Eardley lg. - In coll. SANC.

Zambia: $35 \mathrm{~km} \mathrm{~S}$ Kasama, 10³0'S 31 ${ }^{\circ} 12^{\prime} \mathrm{E}, 1250 \mathrm{~m}$, 12.12.2009, 1 ㅇ , F. Kantner lg. - In coll. OLBL.

Flower visit: On flowers of Harungana madagascariensis (Hypericaceae) and Sapindaceae; all records from Cameroon by A. Pauly.

Derivatio nominis: The new species is dedicated to members of the Halada family (Hamr near Chlum $\mathrm{u}$ Třeboně, Czech Republic). Jiři Halada, the senior, and his sons Marek and Michal collected - sometimes together with other Czech partners - extensive material of Hylaeus from numerous African countries and provided much of their collection to the Biology Centre of the Oberösterreichisches Landesmuseum, Linz (Austria). The material was collected with expertise, the specimens are excellently prepared - it is a joy to work with.

Discussion: This species was discovered only in the wake of a comprehensive revision of the subgenus Hylaeus (Deranchylaeus) (DATHE 2014). Although it had been represented in the checked material, it was not recognized because of its strikingly coarse sculpture on head and mesosoma and was initially assigned to other subgenera for which such features are characteristic. These include in particular the Hylaeus subgenera Metylaeus and Alfkenylaeus.

The new species is consistent with Metylaeus species in the sculpture of the pro- and mesosoma, the anteriorly sharp and laterally tapered pronotum, a margined omaulus and sharp margins around the terminal area of the propodeum; in contrast, H. haladanius spec. nov. has no occipital carina, the metanotum is evenly rounded and punctate and without any remarkable callosities or projections. The male terminalia (Fig. 24) are fundamentally different from Metylaeus. They appear rather similar to H. xanthostoma as a reduced variant. Within the subgenus Deranchylaeus the new species more closely resembles $H$. xanthostoma, because of its similarly coarse thoracic sculpture, at least in the Western populations, for which a larger geographical variation was observed (DATHe 2014: 76).

The present example shows again quite well the mosaic-like distribution of character complexes, which is apparently characteristic of Afrotropical Hylaeus species. There are few characters that separate individual groups. The sickle-shaped mandibles of Nothylaeus are a rare example But they are probably the exception, because even the stylus formation of the gonoforcipes of the male genital capsule can be found in similar forms: even in Alfkenylaeus and Deranchylaeus species. Thornlike structures are common in Cornylaeus (metasoma) and Metylaeus (mesosoma), but they may be missing even in individuals of the same species. Correspondingly, it is difficult to write straightforward and yet 
Assignment to the identification keys to species of Hylaeus (Deranchylaeus) in Dathe (2014: 15-18)

Males (p. 16)

12 Thorax coarsely punctate, with shallowly impressed pits particularly on pleura; pronotum lateral edges pointed; terminal area of propodeum surrounded by sharp margins

- $\quad$ Thorax normally punctate; pronotum edged or rounded; terminal area of propodeum with or without sharp lateral margins

12a Supraclypeal area yellow, like the rest of the mask; pronotum narrow; sculpture of mesosoma varies, but usually without conspicuously coarse punctation; proximal lobes of S7 with few (2-4) bristles, distal lobes formed as a long flag xanthostoma (ALFKEN)

- Supraclypeal area black, rest of mask ivory white or light yellow; pronotum expanded; sculpture of mesosoma with conspicuously coarse punctation; proximal lobes of S7 without bristles, distal lobes formed as a short pennant haladanius spec. nov.

Females (p. 18)

13 Propodeum terminal area circumscribed by a carina, especially with distinct oblique edge between lateral and terminal areae

- Propodeum terminal area sharply edged only ventrolaterally, lateral areas behind without edge

13a Mesosoma conspicuously coarsely punctate; pronotum distinctly expanded, anterior edge sharp, corners pointed; face black haladanius spec. nov.

- Mesosoma normally punctate; pronotum slightly expanded, anterior margin and corners edged; face with bright stripes

reliable identification keys for the subgroups of Hylaeus. Only one fact seems certain: the rich Afrotropical fauna contains many surprises that make our results appear only transitory.

\section{Subgenus Hylaeus (Metylaeus) BRIDWELL}

\section{Species included}

bouyssoui (VACHAL, 1900)

cribratus (BRIDWELL, 1919)

= Metylaeus catalaucoides BRIDWELL, 1919

= Prosopis rugiceps FrIESE, 1921

= Metylaeus semlikiensis CoCKerell, 1936

gaullei (VACHAL, 1900)

lemuriae (BENOIST, 1946)

= Prosopis spiniger BenOIST, 1946

mahafaly HeNSEN, 1987

scutispinus (AlFKen, 1914)

\section{Hylaeus (Metylaeus) bouyssoui (VACHAL, 1900)}

Distribution: Gabon (EARdLey \& URban 2010: 28); new to Central African Republic.

\section{New records:}

Central African Republic: SW, $50 \mathrm{~km} \mathrm{~W} \mathrm{Mbäiki,}$ $04^{\circ} 10^{\prime} \mathrm{N} 17^{\circ} 42^{\prime} \mathrm{E}, 500 \mathrm{~m}, 06.12 .2008,2$ ㅇ, J. Halada lg. $35 \mathrm{~km}$ NE Nola, $03^{\circ} 46^{\prime} \mathrm{N} 16^{\circ} 13^{\prime} \mathrm{E}, 620 \mathrm{~m}, 12.12 .2008$, 1 ㅇ , J. Halada lg. $90 \mathrm{~km}$ NE Nola, $04^{\circ} 07^{\prime} \mathrm{N} 16^{\circ} 37^{\prime} \mathrm{E}$,
$560 \mathrm{~m}, 05 .-09.12 .2010,1$ ㅇ , J. Halada lg. $40 \mathrm{~km}$ S Nola, $03^{\circ} 23^{\prime} \mathrm{N} 16^{\circ} 10^{\prime} \mathrm{E}, 600 \mathrm{~m}, 13.12 .2008,1$ ㅇ, $\mathrm{J}$. Halada lg. $50 \mathrm{~km}$ SW Bangui, $04^{\circ} 04^{\prime} \mathrm{N} 18^{\circ} 14^{\prime} \mathrm{E}, 380 \mathrm{~m}$, 29.04.2010, 1 ㅇ , J. Halada lg. SW, 10 km NNE Mbäiki, $03^{\circ} 56^{\prime} \mathrm{N} 18^{\circ} 00^{\prime} \mathrm{E}, 445 \mathrm{~m}, 01.05 .2010,1$ ㅇ․ J. Halada lg. SW, $20 \mathrm{~km}$ NNE Mbäiki, $03^{\circ} 04^{\prime} \mathrm{N} 18^{\circ} 03^{\prime} \mathrm{E}, 390 \mathrm{~m}$, 02.05.2010, 9 , J. Halada lg. - In coll. OLBL, SDEI.

\section{Hylaeus (Metylaeus) cribratus (BridwelL, 1919)}

Distribution: Angola, Cameroon, Democratic Republic of the Congo, Gabon, Nigeria, Uganda (EARDLEY \& Urban 2010:28); new to Burundi, Central African Republic and Ethiopia.

\section{New records:}

Burundi: Ruvubu National Park, Ruvubu River, 0259'20"S $30^{\circ} 28^{\prime} 12$ "E, $1401 \mathrm{~m}, 05.11 .2010,5$ 우 6 우, C.D. Eardley lg. - In coll. SANC.

Cameroon: NW, $10 \mathrm{~km}$ W Big Babanki, 030ำ $\mathrm{N} 10^{\circ} 11^{\prime} \mathrm{E}$, 900 m, 11.03.2008, 1 ㅇ J. Horák lg. - In coll. OLBL.

Central African Republic: SW, 50 km W Mbäiki, $04^{\circ} 10^{\prime} \mathrm{N}$ $17^{\circ} 42^{\prime} \mathrm{E}, 500 \mathrm{~m}, 06.12 .2008,5$ ㅇ, J. Halada lg. $90 \mathrm{~km}$ NNE Bangui, $05^{\circ} 03^{\prime} \mathrm{N} 18^{\circ} 47^{\prime} \mathrm{E}, 380 \mathrm{~m}, 09.05 .2009$, 1 ; ; 14.03.2010, 17 đo 228 ㅇ, J. Halada lg. $20 \mathrm{~km} \mathrm{NW}$ Bambari, 21.05.2009, 6 o 4 우, J. Halada lg. $95 \mathrm{~km}$ W Sibut, $05^{\circ} 12^{\prime} \mathrm{N} 18^{\circ} 25^{\prime} \mathrm{E}, 24.05 .2009,1$ ㅇ , J. Halada lg. $80 \mathrm{~km} \mathrm{~W} \mathrm{Sibut,} 05^{\circ} 41^{\prime} \mathrm{N} 18^{\circ} 17^{\prime} \mathrm{E}, 25.05 .2009$, 3 ㅇ, J. Halada lg. $45 \mathrm{~km}$ E Nola, $03^{\circ} 32^{\prime} \mathrm{N} 16^{\circ} 26^{\prime} \mathrm{E}$, 08.06.2009, 1 ㅇ, J. Halada lg. 60 km SE Bouar, 05² $42^{\prime} \mathrm{N}$ 
$16^{\circ} 00^{\prime} \mathrm{E}, 860 \mathrm{~m}, 30.03 .2010,1$ , J. Halada lg. $85 \mathrm{~km}$ NW Bangui, $04^{\circ} 46^{\prime} \mathrm{N} 18^{\circ} 04^{\prime} \mathrm{E}, 380 \mathrm{~m}, 04.04 .2010,1$ ㅇ, J. Halada lg. $70 \mathrm{~km}$ NNE Bangui, $04^{\circ} 57^{\prime} \mathrm{N} 18^{\circ} 46^{\prime} \mathrm{E}$, $430 \mathrm{~m}, 08.04 .2010,4$ 우 J. Halada lg. SW, $10 \mathrm{~km}$

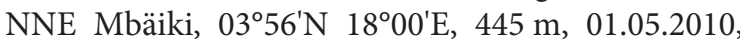
1 오․ J. Halada lg. SW, $20 \mathrm{~km}$ NNE Mbäiki, $03^{\circ} 04^{\prime} \mathrm{N}$ $18^{\circ} 03^{\prime} \mathrm{E}, 390 \mathrm{~m}, 02.05 .2010,2$ 우 J. Halada lg. - In coll. OLBL, SDEI.

Ethiopia: W Hararge Mechara, $08^{\circ} 36^{\prime} \mathrm{N} \quad 40^{\circ} 19^{\prime} \mathrm{E}$, 17.-21.01.2011, 1 ㅇ an Verninia auriculifera, A. Pauly lg. - In coll. RBINS, HBRC.

Nigeria: Gashaka Gumfi NP, 25 km SW Serti env., $07^{\circ} 20^{\prime} \mathrm{N}$ $11^{\circ} 13^{\prime} \mathrm{E}, 400 \mathrm{~m}, 09 .-13.05 .2011,3$ ㅇ, J. Halada lg. - In coll. OLBL.

\section{Hylaeus (Metylaeus) lemuriae (BENoIst, 1946)}

Distribution: Madagascar (EARDLEY \& URBAN 2010: 31).

\section{New records:}

Madagascar: Parc National Isalo, Ranohira vicinity, $22^{\circ} 32^{\prime} 28^{\prime \prime S} 45^{\circ} 23^{\prime} 15^{\prime \prime E}, 777 \mathrm{~m}, 14 .-15.10 .2004,30^{*}$ 1 \% Parc National Zombidse, $20 \mathrm{~km}$ N Sakaraha, $22^{\circ} 53^{\prime} \mathrm{S} 44^{\circ} 41^{\prime} \mathrm{E}, 700 \mathrm{~m}, 14.10 .2004,6$ \% ; Ranomafana $10 \mathrm{~km}$ E, Mahakajy Reserve, $21^{\circ} 15^{\prime} \mathrm{S} 47^{\circ} 57^{\prime} \mathrm{E}, 1$ 우, C.D. Eardley lg. - In coll. SANC.

\section{Hylaeus (Metylaeus) mahafaly HensEN, 1987}

Distribution: Madagascar (EARDLEy \& URBAN 2010: 32).

\section{New records:}

Madagascar: Toliara $27 \mathrm{~km} \mathrm{~N}$, Trockenwiese bei Ifaty, 09.-13.11.2003, 7 o 1 ㅇ, J. Oehlke lg. - In coll. SDEI. Tulear $4 \mathrm{~km} \mathrm{~N}, 23^{\circ} 18^{\prime} \mathrm{S} 43^{\circ} 39^{\prime} \mathrm{E}, 50 \mathrm{~m}, 17.10 .2004$,

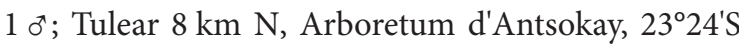
$43^{\circ} 45^{\prime} \mathrm{E}, 50 \mathrm{~m}, 19.10 .2004$, on Azadiracta indica, $8 \mathrm{o}^{\circ}$ 3 , C.D. Eardley lg. - In coll. SANC.

\section{Hylaeus (Metylaeus) scutispinus (ALFKEN, 1914)}

Distribution: Botswana, Burkina Faso, Kenya, Namibia, Zimbabwe (EARDley \& Urban 2010: 36); new to Benin, Central African Republic, Ethiopia, Malawi, Mozambique and South Africa.

\section{New records:}

Benin: SE $15 \mathrm{~km}$ SE Save, riv. Okpara, 26.04.2000, $20^{\star}$. SE Save $15 \mathrm{~km} \mathrm{SE}, 08 .-25.04 .2000,10 o^{\top} 1$ 우, J. Halada lg. - In coll. OLBL.

Botswana: N Maun, Island Sateri, 01.-31.01.1997, $20^{*}$ 2 ㅇ, M. Snižek lg. - In coll. OLBL.

Central African Republic: Res. Koukorou-Bamingui, $07^{\circ} 15^{\prime} \mathrm{N} 20^{\circ} 03^{\prime} \mathrm{E}, 440 \mathrm{~m}, 20.04 .2010,2$ , J. Halada lg. - In coll. OLBL.
Ethiopia: Awash National Park, $08^{\circ} 55^{\prime} \mathrm{N} \quad 40^{\circ} 02^{\prime} \mathrm{E}$, 20.-21.07.2011, 2 ค, A. Pauly lg. - In coll. RBINS, HBRC.

Kenya: E of Aveta, 07.04.2007, 1 ○, M. Halada lg. Voi Safari Lodge env., Tsavo National Park East, 08.-18.11.1996, 4 ơ; 22.11.-02.12.1996, 11 ơ; 11.-14.04.1997, 1 o', M. Halada lg. SE Voi Safari Lodge env., Tsavo National Park East, 10.12.1999, 10 o 1 \%, M. Snižek lg. - In coll. OLBL.

Malawi: Liongwe $80 \mathrm{~km} \mathrm{E,} \mathrm{Selima} \mathrm{env.,} \mathrm{03.-04.01.2002,}$ 7 o 20 ㅇ, J. Halada lg. - In coll. OLBL.

Mozambique: CW, $15 \mathrm{~km} \mathrm{~S}$ Guro, $17^{\circ} 33^{\prime} \mathrm{S} 33^{\circ} 16^{\prime} \mathrm{E}, 800 \mathrm{~m}$, $30.11 .2005,20^{\top}$; CW, Chimoio $40 \mathrm{~km}$ SW, 19² $26^{\prime} \mathrm{S}$ $33^{\circ} 11^{\prime} \mathrm{E}, 650 \mathrm{~m}, 16.12 .2005,6$ o $^{*}$, Kadlecová lg. - In coll. OLBL.

South Africa: KwaZulu-Natal: Tembe Elephant Park,

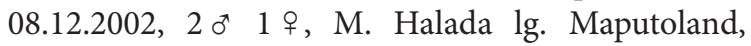
eManguzi SW, 29.01.2003, 29 o 5 우, M. Snižek lg. Tembe Elephant Park env., Jozini, 22.01.2003, $20^{\star}$, V. Křivan lg. - In coll. OLBL. [Transvaal:] Blyderivierspoortdam Nat. Reserve, $24^{\circ} 32^{\prime} \mathrm{S} 30^{\circ} 47^{\prime} \mathrm{E}$, 25.-26.10.1984, $10^{\star}$, C.D. Eardley lg. Gauteng, Soutpan, $25^{\circ} 24^{\prime} \mathrm{S} 28^{\circ} 06^{\prime} \mathrm{E}, 02.03 .2005,10^{\star} 3$ 우 10.03.2005, 1 ㅇ, C.D. Eardley lg. - In coll. SANC.

Namibia [SWA]: Kaoko Otavi, 01.-31.03.1926, 1 ○’, Mus. Exped. lg. - In coll. SAMC.

Zimbabwe: Bubi, Bubi riv., $80 \mathrm{~km}$ NE Beitbridge, 08.12.1998, $1 \sigma^{\star}$, J. Halada lg. Chimanimani Nature Park, 14.12.1998, 1 ๙ , M. Halada lg. Mavhuradonha Saf. A., $15 \mathrm{~km}$ SE Muzarabani, 17.12.1998, 2 ㅈ 1 ㅇ, M.\& J. Halada lg. Mushandike Sanctuary Masvingo 09.-11.12.1998, 1 đ 2 ㅇ, M. Halada lg.; 10.12.1998, 12 ○ 2 ㅇ, J. Halada lg. - In coll. OLBL.

\section{Subgenus Hylaeus (Prosopisteron) CockeRELL, 1906}

The only species found in Africa, Hylaeus (Prosopisteron) perhumilis, is originally home in Australia and New Zealand.

\section{Hylaeus (Prosopisteron) perhumilis (COCKERELL, 1914)}

SNELLING (1985) described this introduced species from Africa as Psilylaeus sagiops with records from the years 1930-1948. Later (1988) he stated the synonymy (Michener 2007: 212). There are some more specimens in South African museums, which were not listed by SNELLING. Among them is a last record from December 1985, from near the town Kleinmond (Western Cape). It is therefore conceivable that further populations have survived locally, but apparently they have not spread out from these points.

\section{Additional records:}

South Africa: Western Cape [CP]: Mossel Bay, 11.12.1941, 1 \&, R. Turner lg. - In coll. SAMC. Grahamstown, 
24.04.1956, 1 ㅇ, E. McC.Callan lg.; 05.04.1958, 1 ㅇ, C. Jacot-Guillarmod lg. - In coll. AMG. Western Cape [CP]: Palmiet River nr Kleinmond, $34^{\circ} 21^{\prime} \mathrm{S} 1^{\circ} 03^{\prime} \mathrm{E}$, XII.1985, 1 ㅇ, O. Neser lg. - In coll. SANC.

\section{Subgenus Hylaeus (Pumilaeus) subgen. nov.}

Type species: Hylaeus pumilus spec. nov.; loc. typ.: Cameroon, N Mindif, bord Mayo Boula.

The relevant characters are explained in more detail in the following species description. Which of them actually are diagnostic of the group depends on the possible discovery of other related species. Currently there is no similar species known in the region.

Description: This subgenus is characterized mainly by the terminalia of the male (Fig. 25). The genital capsule is oval in outline, with penis valves in the dorsal view apically broadly rounded, the apical bristles long and converging. Sternum 7 is unique: with distal lobes expanded into a pair of convex bubble-like surfaces without clear subdivision into proximal and distal parts, and without bristles. Sternum 8 is a little reminiscent of certain Palaearctic Hylaeus (Nesoprosopis) species: with apical lobus prolonged, narrow, apically divided into two round lamellae with fine marginal bristles.

According to the identification keys by SNELLING (1985), Michener (2007) and Dathe (2014), one can exclude the subgenera Alfkenylaeus, Cornylaeus, Metylaeus, Nothylaeus and Prosopisteron. So far Pumilaeus subgen. n. shows a number of exclusion criteria to those subgenera, but few special features of its own: (1) The sculpture of the mesosoma is regular, not coarse, with fine to moderate, dense punctation, (2) occiput and propodeum are rounded, (3) the mandibles bifid. But among the known species, Pumilaeus subgen. n. also delimits sufficiently clearly from Deranchylaeus: On the head, (4) the vertex is narrow and backward sloping with rounded transition; (5) the foveae faciales are extended to the vertex, where they converge strongly. The antennae are short. (6) The supraclypeal area is very flat and only faintly raised above the curvature of the face in lateral view, its lateral edges are without sharp ridges; above it merges relatively broadly into the vertex, wherein the females have in addition to the median furrow four to five striking parallel grooves on each side. Finally, (7) the very short, rounded pronotum, not expanded forward, distinguishes this taxon from the known Deranchylaeus species.

\section{Hylaeus (Pumilaeus) pumilus spec. nov.}

Figures 18-21, 25

Diagnosis: This is a small dainty species, possessing special characters in male terminalia (see above).

Description: Male. - TL $4.65 \mathrm{~mm}$, WL $2.95 \mathrm{~mm}$. Head. Proportions HL:HW 0.89, UFW:LFW 1.91, outline transverse trapezoid. Scapus short, conical, as wide as flagellum, SL:SW 1.7; predominantly white-marked, only the back blackish; flagellum short, yellow, darkened above. Mask ivory white, complete. Foveae faciales indistinct, only recognizable on vertex as a smooth line. Clypeus CL:CW 1.38, silkily shining, with moderate, dense punctation; supraclypeal area with oval impression above, dorsally rounded. Pilosity on frons and vertex very sparse, punctation moderate, subcontiguous with smooth interspaces. Occiput edged, malar areas narrow. Labrum and mandibles black.

Mesosoma. Shape relatively short, compact. Pilosity sparse, short, only at seams between mesonotum, scutellum and metanotum with white felt. Black with bright marks on pronotum, calli and tegulae. Pronotum with white line, narrow, not expanded; anterior margin rounded, posterolateral angle blunt. Mesonotum shagreen, silkily shiny, punctation fine, contiguous to subcontiguous, scutellum with somewhat more scattered punctation, shiny; mesopleura also shagreen, silkily shiny, and punctation more scattered than mesonotum. Sculpture of metanotum other than mesonotum and scutellum, similar basal area with wrinkled meshes. Legs black; bright are the femur tips, tibiae and entire tarsi. Wings hyaline, venation brown. Propodeum rounded, basal area delimited by carina, surface with sharply defined wrinkles; terminal area only laterally and ventrally with sharp margins, on surface with fine wrinkled sculpture, median sulcus expanded like a funnel above.

Metasoma slender, spindle-shaped, surface with short and close white hairs; coloration black. Sculpture of T1 smooth and shiny, with fine, subcontiguous to dense punctation; punctation of following terga still finer, flat and densely punctate. T1 with narrow white lateral fringes. Terminalia see Fig. 25 and description above.

Female. - TL 5.2-5.3 mm, WL 3.6-3.8 mm.

Head. Proportions HL:HW 0.86-0.87, UFW:LFW 1.52, outline transverse-elliptic. Scapus black. Flagellum long, yellow, darkened above. Face markings ivory white, paraocular markings filling lateral parts of face, extended above to foveae. Foveae faciales expanded to vertex, strongly converging. Clypeus CL:CW 1.02-1.06 (1.04), shagreen, matt, with dense flat punctation. Supraclypeal area relatively flat and wide, merging above with stripes/ grooves onto forehead. Frons and vertex with moderate, subcontiguous punctation. Genae and occiput regular, malar areas narrow. Labrum and mandibles brown, mandibles bifid. 
Mesosoma compact; pilosity dorsally very short, closely adpressed, ventrally long and erect; pronotum with bright stripe, calli and tegulae with spots. Pronotum not expanded, dorsolateral angle rounded. Mesonotum with fine, dense punctation, intervals shagreen, silkily shiny. Scutellum with more scattered punctation, shiny; mesopleurae shagreen with moderate, close punctation. Sculpture of metanotum with wrinkled meshes, similar to basal area of propodeum. Legs black, bright are tibial bases outside and apical tarsi. Wings hyaline, venation brown. Propodeum rounded, matt; basal area delimited by sharp reticulate wrinkles, shiny; terminal area with sharp edges only laterally below, surface shagreen, matt, with white hairs; medial furrow smooth, expanded above.

Metasoma shape compact, spindle shaped, coloration black but base of T1 ferruginous, surface covered with short white pubescence. Sculpture of T1 smooth and shiny, with fine, dense punctation, becoming denser toward the apical margin; following terga with very minute shallow punctation; T1 to T3 with narrow white lateral fringes and interrupted white hairband on depression. Terminal ventral fringe pale.

\section{Distribution: Cameroon.}

Type material: $1 \sigma^{\star}, 2$ ㅇ.

Holotypus: $0^{\top}$ Cameroon: N Mindif, bord Mayo Boula, $10^{\circ} 27^{\prime} \mathrm{N} 14^{\circ} 25^{\prime} \mathrm{E}, 30.07 .1987$, A. Pauly lg. - In coll. RBINS. Paratypes: Cameroon: same data as holotype, 2 ㅇ, A. Pauly leg. - In coll. RBINS, SDEI.

Flower visit: On flowers of Cassia sp. (Fabaceae), record by A. Pauly.

Derivatio nominis: The species (and subgenus) name is derived from pumilio (lat.) - dwarf and refers to the dainty shape of the new species. The term is used adjectivally, as it has been defined by the principles of zoological nomenclature since LINNAEUs in 1758.

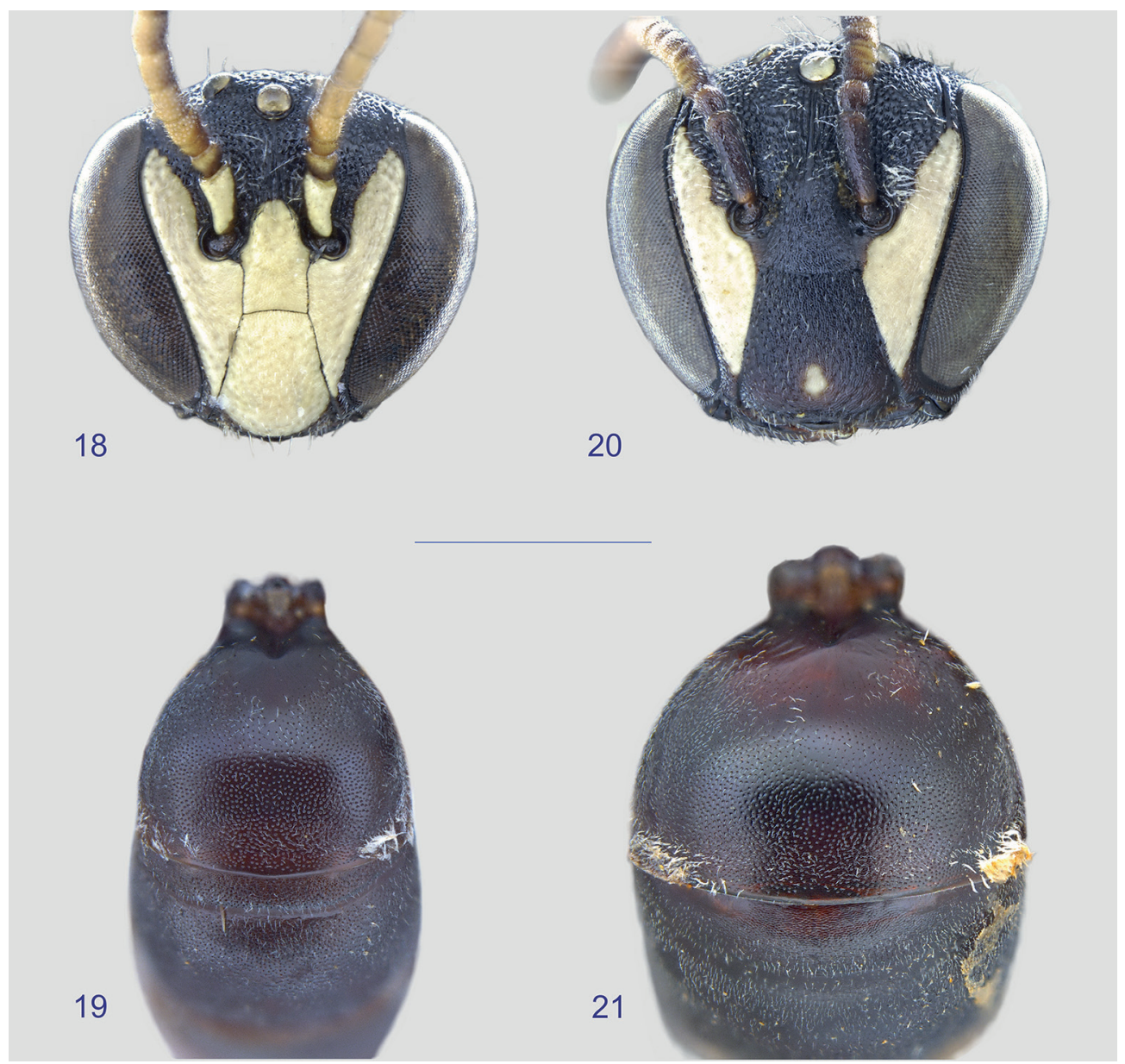

Figs 18-21: Hylaeus (Pumilaeus) pumilus spec. nov.: head in frontal view and surface structure of basal terga in dorsal view. - 18, 19 Typus male. - 20, 21 Paratypus female. - Scale $1 \mathrm{~mm}$. 

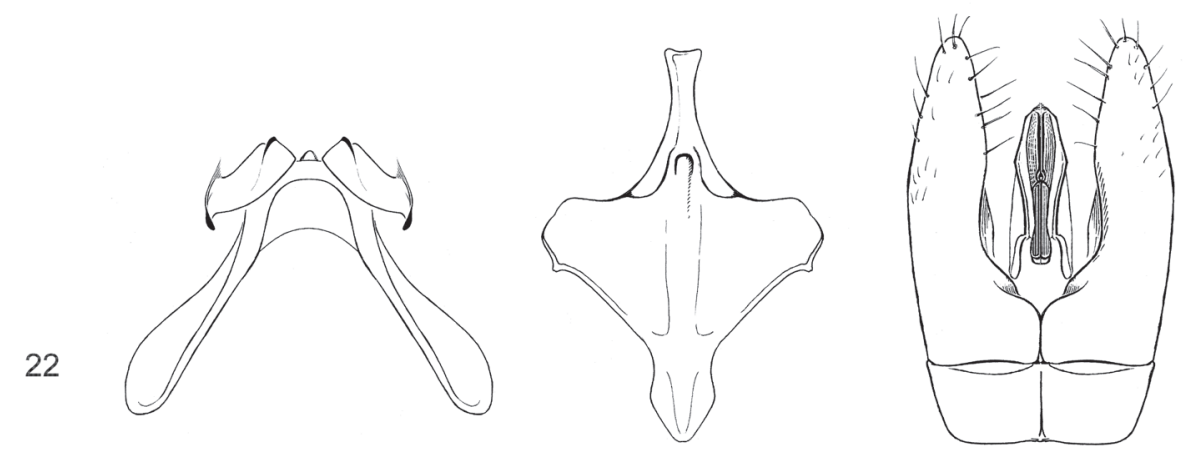

euphorbiae

23
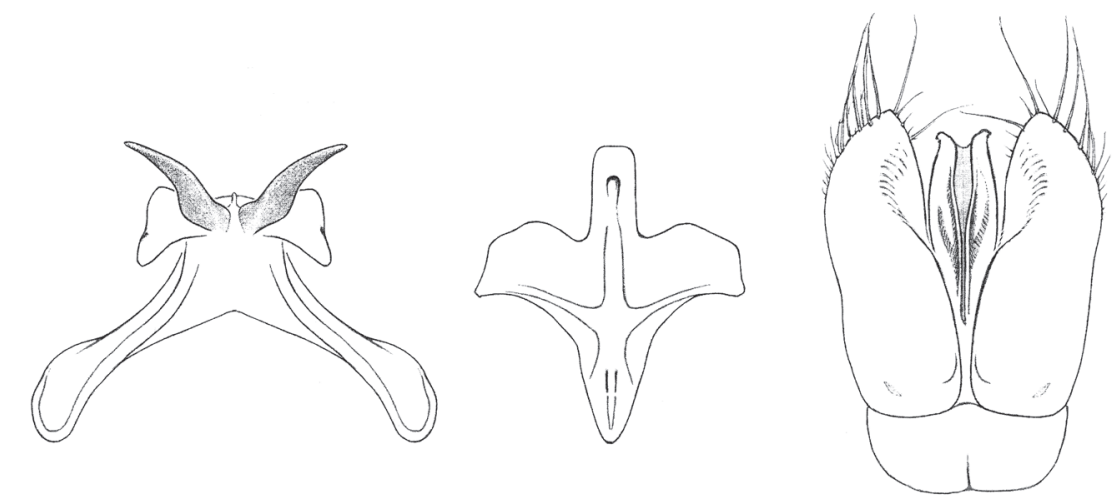

adamauanis

24
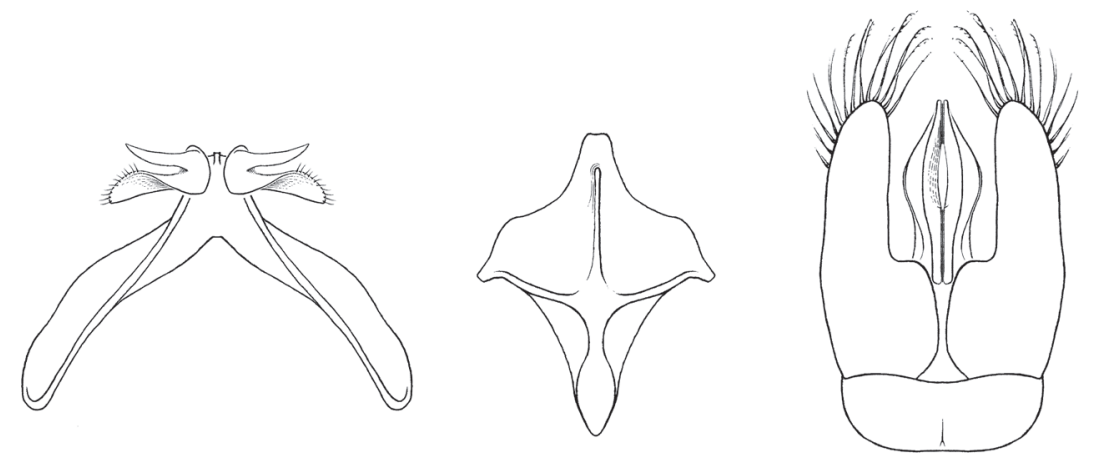

haladanius
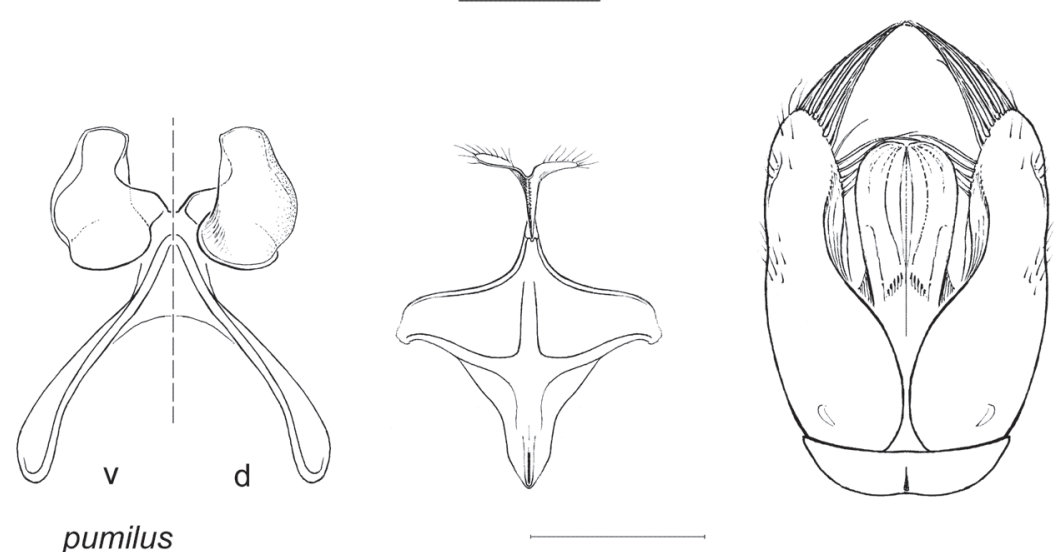

Figs 22-25: Male terminalia: metasomal sterna 7 and 8 (S7, S8), genital capsule. - 22 Hylaeus (Alfkenylaeus) euphorbiae spec. nov. - 23 Hylaeus (Cornylaeus) adamauanis spec. nov. - 24 Hylaeus (Deranchylaeus) haladanius spec. nov. - 25 Hylaeus (Pumilaeus) pumilus spec. nov., S7: left ventral view, right dorsal view. - Scale $0.2 \mathrm{~mm}$. 


\section{Acknowledgments}

The National Research Foundation (NRF) of South Africa is acknowleged for financial support of research in South African museum collections. I am particularly grateful to Connal D. Eardley (SANC, Agricultural Research Council, Pretoria), who not only inspired this investigation but supported it scientifically and logistically; I also owe him several substantial improvements of this manuscript. I hold the South African National Collection of Insects (SANC) of the Agricultural Research Council, Pretoria, as suited in the best possible way to serve as a reference centre for African species of wild bees.

For the generous provision of excellent working facilities at the SDEI, I thank the Senckenberg Gesellschaft für Naturforschung, Frankfurt am Main.

The natural history museums of South Africa, especially in Pretoria, Grahamstown and Cape Town, were all involved in the completion of this work. Valuable material was made available by the Museum für Naturkunde, Berlin, Germany, the Royal Belgian Institute of Natural Sciences, Brussels, Belgium, the Biologiezentrum of the Oberösterreichisches Landesmuseum, Linz, Austria, and the Natural History Museum London, U.K. For this I heartily thank Connal D. Eardley (Pretoria), Dawn Larsen and Simon van Noort (Cape Town), Sarah K. Gess and John Midgley (Grahamstown), Frank Koch and Viola Richter (Berlin), Alain Pauly (Brussels), Fritz Gusenleitner (Linz), David G. Notton and Michael Kuhlmann (London). In preparing the final version of the English language text I was assisted as reliably as always by Andrew Liston (SDEI Müncheberg).

\section{References}

Some annual data of this reference list are indexed as used by EARDLEY \& URBAN (2010) to facilitate the literature search in special cases.

Alfken, J. D. 1914: Zur Kenntnis der afrikanischen Prosopis-Arten. (Hym.). - Deutsche Entomologische Zeitschrift 1914 (2): 183-197. http://dx.doi.org/ 10.1002/mmnd.191419140213.

Benoist, R. 1946: Nouvelles espèces d'Apides (Hym.) de Madagascar. - Bulletin de la Societé entomologique de France 50 (1945): 131-135.

BridWELL, J. C. 1919: Miscellaneous notes on Hymenoptera with descriptions of new genera and species. - Hawaiian Entomological Society, Proceedings 4: 109-165.

Cockerell, T. D. A. 1914b: VII. - Descriptions and records of bees.- LXII. - Annals and Magazine of Natural History, Series 8, 14: 49-57.

Cockerell, T. D. A. 1936p: LXIV.- Descriptions and records of bees. - CLVIII. - Annals and Magazine of Natural History, Series 10, 18 (108): 631-638.
Cockerell, T. D. A. 1942f: Bees of the family Hylaeidae from the Ethiopian Region. - Smithsonian Miscellaneous Collections 101: 1-15.

DAthe, H. H. 2014: Studies on the systematics and taxonomy of the genus Hylaeus F. (8). Revision of the Afrotropic subgenus Hylaeus (Deranchylaeus) Bridwell (Hymenoptera: Anthophila, Colletidae). Zootaxa 3874 (1): 1-84.

EARDLEY, C. \& URBAN, R. 2010: Catalogue of Afrotropical bees (Hymenoptera: Apoidea: Apiformes). - Zootaxa 2455: 1-548.

Eardley, C.; Kuhlmann, M. \& Pauly, A. 2010: The bee genera and subgenera of sub-Saharan Africa. - In: Van den Spiegel, D. (ed.) Abc Taxa, the Series of Manuals dedicated to capacity building in taxonomy and collection management, Tervueren. Vol. 7: $138 \mathrm{pp}$.

Friese, H. 1913b: Neue Bienenarten aus Afrika. Deutsche Entomologische Zeitschrift 1913: 573-578.

Hensen, R. V. 1987: Hylaeus (Metylaeus) mahafaly spec. nov., a new Malagasy bee (Hymenoptera: Apidae). - Entomologische Berichten, Amsterdam 47: $152-154$

Michener, C. D. 2000: The Bees of the World. The Johns Hopkins University Press, Baltimore and London: 913 pp.

Michener, C. D. 2007: The Bees of the World. Second Edition. The Johns Hopkins University Press, Baltimore and London: 953 pp.

Pauly, A. 1984: Mission entomologique en Afrique Occidentale (1979-80): Renseignements eco-biologiques concernant les Hyménoptères. - Notes fauniques de Gembloux 11: 1-43.

Pauly, A. 1998: Hymenoptera Apoidea du Gabon. - Annales Sciences zoologiques, Musée royal de l'Afrique centrale, Tervuren 282: 1-121.

PAulY, A. 2011-2012: Localities of collecting trips in Ethiopia, GTI projects 1-3 (October 2010 September 2012). Available from: http://zoologie. umh.ac.be/hymenoptera/page.asp?ID=168 (accessed 30 April 2014).

Pauly, A.; Brooks, R. W.; Nilsson, L. A.; Pesenko, Y. A.; Eardley, C. D.; Terzo, M.; Griswold, T.; Schwarz, M.; Patiny, S.; Munzinger, J. \& Barbier, Y. 2001: Hymenoptera Apoidea de Madagascar et des Iles Voisines. - Annales Sciences Zoologiques, Tervueren 286: $1-390$.

SNelling, R. R. 1985: The systematics of the hylaeine bees (Hymenoptera: Colletidae) of the Ethiopian zoogeographical region: The genera and subgenera with revisions of the smaller groups. - Contributions in Science, Natural History Museum of Los Angeles County, no. 361: 1-33.

VACHAL, J. 1900: Contributions hyménoptériques. III. Prosopis nouvelles de l'Afrique équatoriale occidentale. - Annales de la Société Entomologique de France 68 (1899): 535-536. 